\title{
THE PERFORMANCE ANALYSIS OF THE URBAN FLOOD PREVENTION PROJECT IN KOREA
}

\author{
JUNGNAM PARK, JEONGMIN KWON, SANGWON HAN, BYOUNGMANN PARK, JUNGGYU HAN, \\ JUNGHYUN HWANG \& SEOKHYUN CHUNG \\ Department of Sewerage, Korea Environment Corporation, South Korea
}

\begin{abstract}
The frequency of intensive rainfall keeps increasing due to climate change. Some areas in downtown Seoul were flooded by localized heavy rainfall (2010 and 2011). The Ministry of Environment of the Republic of Korea prepared the "Comprehensive Plan on Sewerage Maintenance against Urban Flooding" in 2012 in order to eliminate flooding by improving sewer systems in selected 6 areas in consideration of regional representation. As a model, 232.7 billion KRW (210 million USD) was invested at the 6 selected sites for upgrading the drainage infrastructures. They expanded sewer infrastructures such as storm water pipelines, detention facilities and pumping stations. We analysed the achievements of the urban flood prevention projects. The performance of exemplary projects includes: 1) eliminating flooding in 30-year frequency rainfalls;2) simulating a dual drainage system in Korea for the first time; 3 ) developing a rainfall runoff model suitable for Korean situations; 4) applying sewage drainage tunnels; 5) applying Real Time Control (RTC) for sewage systems. As a result of the fundamental solution to the problem of repetitive flooding, 54,299 households in $15.1 \mathrm{~km}^{2}$ became safe from flooding by improving drainage facilities in various ways. Also, the quality of life of residents got better by creating a comfortable and safe environment. Based on the performance of these exemplary projects, Korean government will select 107 flood prevention areas by 2025 and promote flooding prevention projects.
\end{abstract}

Keywords: storm water, climate change, urban flood, sewer system, rainfall, flood prevention, drainage facility, SWMM.

\section{INTRODUCTION}

Recently, heavy rainfall occurred frequently and there were many floods in the urban area in Korea every year. It is because the capacity of sewerage facilities is not sufficient for draining the intensive rainfall. The policy of sewer system in Korea focused on only water quality management, such as the construction of sanitary sewer and Publicly Owned Treatment Works (POTW) which helped to reach up to $92.9 \%$ of sewer service rate recently in Korea [1]. But there has been a lack of interest and investment in storm water management in sewerage and the increased flood damage in the urban area was threatening the safety of residents.

The drain capacity was insufficient compared to the intensive rainfall caused by climate change. In order to prepare for preventing flood, rehabilitation model for drainage system applying regional characteristics was developed, and it has become increasingly important to establish a safe urban environment and to improve related systems. Therefore, the government started the model projects with the first trial to prevent the urban flood, and prepared comprehensive urban sewage countermeasures to improve the drainage capacity of public sewerage systems. In consideration of the sewerage type and area size, 6 cities were selected as the area for the projects.

\section{CAUSES OF URBAN FLOODING}

The major cause of urban flooding can be summarized as follow. The topographical factors, the changes of the rainfall pattern, the rainfall runoff conditions, the influences of the discharge stream, the problems of the sewage facilities in operation and maintenance, 
the problems of low lying lands and the problem of measures to overcome the flooding can be the reason of urban flooding

The first cause is topographical factors. Typhoons and heavy rainfall cause rapid flooding in the gently sloping pipelines due to the rapid inflows from the mountainous areas, thus increasing flood damage.

The second is the change of rainfall pattern. The direct causes of inundation in urban areas are heavy rains caused by repetitive typhoons and seasonal rainfalls that occur in summer between July and August every year. Variation in rainfall patterns with climate change indicates that the rainfall in rainy season increased by $39.5 \%$ in the 2000 s compared to the 1970s (Fig. 1). On the other hand, rainfall in dry season (December, January, February) decreased by $15 \%$ in same period (Fig. 2).

The third is the change of rainfall runoff condition. As the impervious area increases due to the rapid urbanization and the industrial development nationwide as shown in Fig. 3 [3], the outflow volume of the rainfall greatly increases, the duration of the intensive rainfall extended while the surface runoff amount of the rainfall has increased as shown in Fig. 4 [3].

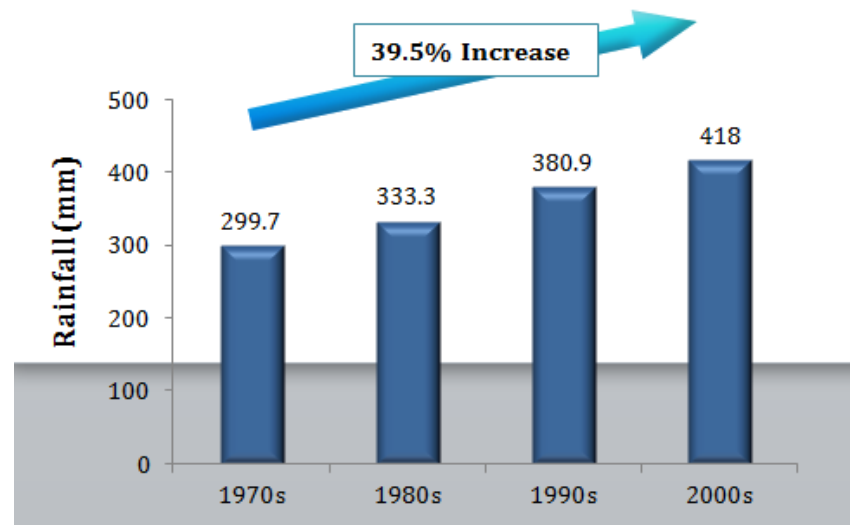

Figure 1: Rainfall changes in Seoul during the rainy season (July, August).

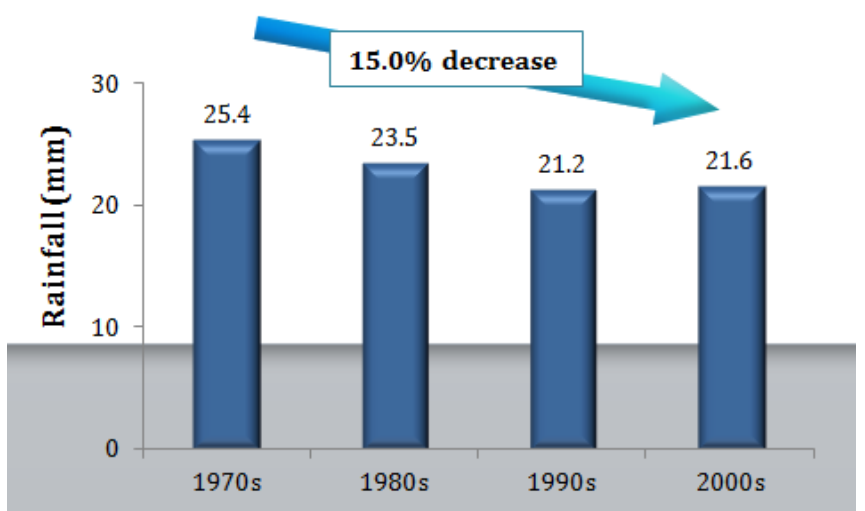

Figure 2: Rainfall changes in Seoul during dry period (December, January, February). 


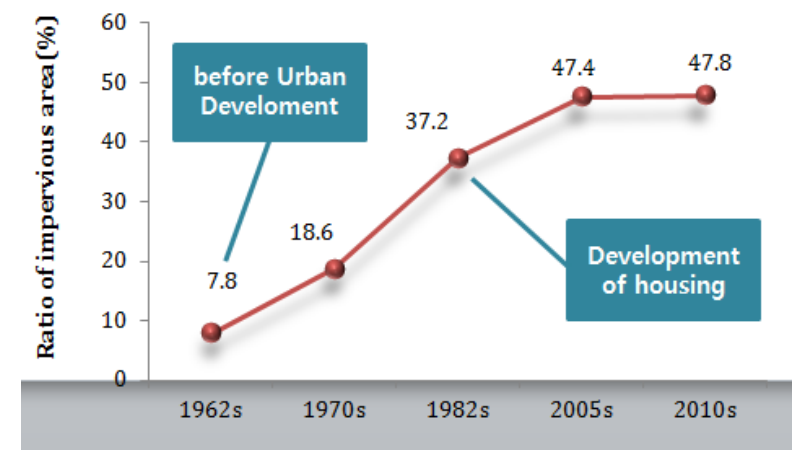

Figure 3: Increase in impervious area (Seoul).

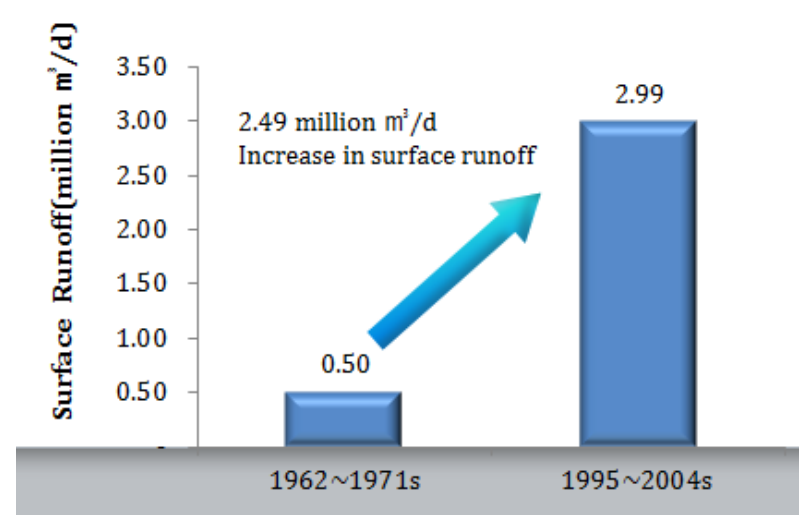

Figure 4: Increase of surface runoff (Seoul).

The fourth is the influence of the water level in discharge stream. The damage of inundation and backward flow from rising water level of discharge stream is further increased the damage of urban flooding.

The fifth is the problem of conveying storm water which is inadequate drainage capacity and the problem on rainfall drain system such as road drainage, etc. These problems account for $73 \%$ of total domestic flooding.

The sixth is the poor management of sewer system. Storm water is disposed of using the sewerage system in Korea. The insufficient maintenance and aging of the sewer pipe makes the discharge capacity of the pipeline is lowered, which increases urban flooding.

The seventh is the sewer policy focused on water quality management such as the sanitary sewer construction which cause the lacking in interest and budget investment, and the sewerage capacity was insufficient compared with the intensive rainfall due to climate change. It is threatening the safety of residents.

Finally, it is the problem regarding with institutional countermeasures against the flooding. As the measures are focused on disaster recovery of the flood damage, Investment and effort for preventing flood was not sufficient and the comprehensive countermeasures against inundation prevention were not established. 


\section{THE IMPLEMENTATION OF PROJECT FOR URBAN FLOOD PREVENTION}

In May 2012, the Korean government prepared comprehensive urban sewage countermeasures for eliminating urban flood including the improvement of the drainage capacity of public sewerage systems. In consideration of the sewer drain system and area size, the government selected the following six cities and spent KRW 237.4 billion (210 million USD) to implement model projects for urban flood for 5 years until 2016. Since it is the first-trial for flood prevention in Ministry of Environment (MOE), Korea Environmental Corporation (KECO) which took charge of the host and have successfully carried out the 6 projects according to the following procedure.

\subsection{The field surveys}

They are conducted to inspect the status of sewer system and verify the reliability of the sewer record sheet. The results of the survey are used as basic data for the simulation which is used to predict the appropriateness and effect of the flood control facilities. It conducts surveys, surveying, internal inspection (CCTV and visual inspection), water quality and flow investigation, soil investigation, and flood history investigation of all sewers installed in the project area.

\subsection{The analysis of causes and problems of flood}

Analyse the current condition and problems of drainage facilities such as pumping stations, reservoirs, storm drains, and causes of flooding.

\subsection{Establishment of rehabilitation targets for sewage facilities in rainfall}

Sewer systems are set to prevent flooding from 10 to 30 years frequency of rainfall and sewer pump station and storage tanks are set to prevent flooding from 30 to 50 years frequency of rainfall [2].

\subsection{The calculation of rainfall flow rate and the simulation for flood occurrence}

Calculate the probability rainfall for flooding area and drainage basin. According to the probability rainfall, Flow rate of rainfall in sewer system is calculated considering rainfall distribution, duration, surface condition, and impervious rate. Finally, Simulate and predict the appropriateness and effect of the flood control facilities using the dual drainage system rainfall runoff analysis model "Storm Water Management Model (SWMM)".

\subsection{The specific plan of sewage facilities for flood prevention}

The sewer system should be expanded to prevent flooding even at 10 to 30 years frequency. If the space for installation of facilities not enough, a bypass line should be installed to separate the watershed. It makes storm water drains properly. The pumping station should be equipped with sufficient capacity in 30 50 years frequency of rainfall [2] by expansion or construction of pump station in connection with the expansion of sewer system as shown in Fig. 5.

The storage tank or a storage tunnel underground that temporarily stores rainwater in excess of capacity in areas where it is difficult to improve the sewer system is installed like Fig. 6. 


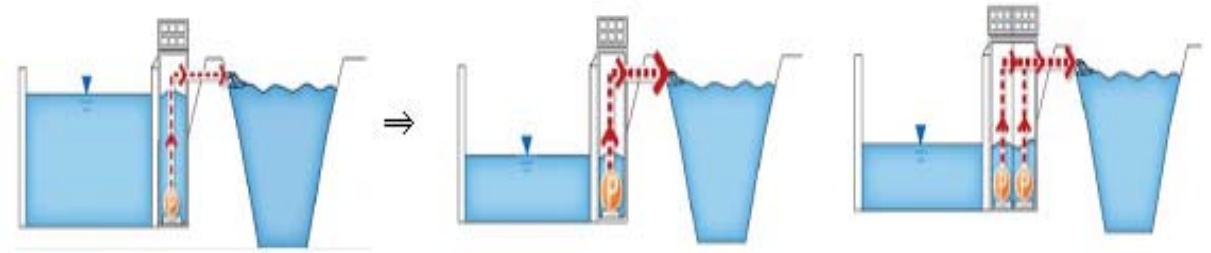

Figure 5: Pump station capacity shortage - replace of pump with high capacity expansion of pump station.
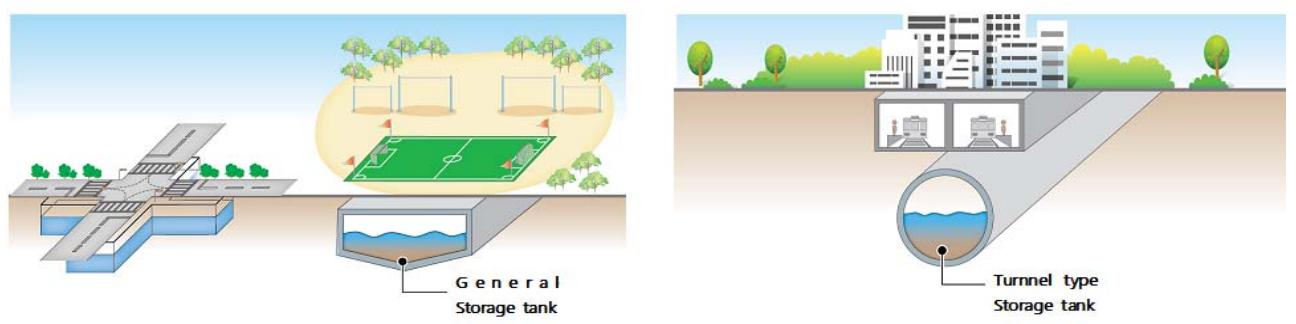

Figure 6: The storage tank for preventing flood.

\subsection{Build a Real Time Control system (RTC).}

Real-time monitoring data such as rainfall, discharge river water level, sewage pipe, pump station, etc. makes it possible to implement a system that can automatically control facilities. By analysing the regional characteristics such as sewage characteristics and sewer system type as mentioned above, the rehabilitation and maintenance plan was prepared for six cities. Main contents of drainage system maintenance for flood prevention in 6 cities are shown in the following Table 1. The drainage tunnel $(\mathrm{D}=3 \sim 3.5 \mathrm{~m})$ was first introduced in Bucheon and Cheonan for rainwater.

\section{ANALYSIS OF FLOOD PREVENTION PROJECT PERFORMANCE}

\subsection{The elimination of urban flooding}

As a result of the fundamental solution to the problem of repetitive flooding, Sewage facilities were installed and 54,299 households in $15.1 \mathrm{~km}^{2}$ became safe from flooding in the area of model projects in Table 2. Also, the quality of life of residents was improved by creating a comfortable and safe environment.

\subsection{Increase land use efficiency}

Increase the added value of the areas designated by the future city planning as urbanization area or residential areas, and increase the added value of low-lying land near flooded areas 
Table 1: Characteristics and rehabilitation measures for model projects.

\begin{tabular}{|c|c|c|c|}
\hline City & Local Characteristics & Maintenance & Measures \\
\hline 1. Gimhae & $\begin{array}{l}\text { Low lying area by the } \\
\text { influence of external water } \\
\text { level and rainwater pumping } \\
\text { Sanitary Sewer System }\end{array}$ & $\begin{array}{l}\text { Uses existing facilities } \\
\text { through parallel pipelines } \\
\text { and upstream watersheds } \\
\text { Establishment of a storm } \\
\text { water pumping station by } \\
\text { adjustment of drainage } \\
\text { watershed }\end{array}$ & $\begin{array}{l}\text { Sewer line: } 6.97 \mathrm{~km} \\
\text { Pumping station: } \\
1,200 \mathrm{~m}^{3} / \mathrm{min} \cdot \\
\text { Lagoon: } 20,000 \mathrm{~m}^{3} \\
\end{array}$ \\
\hline 2. Bucheon & $\begin{array}{l}\text { Shortage of main pipelines } \\
\text { capacity on merged area, flat } \\
\text { terrain, natural river basin } \\
\text { Sanitary Sewer System }\end{array}$ & $\begin{array}{l}\text { Overcoming the limit of } \\
\text { the drainage system in the } \\
\text { river culvert } \\
\text { Underground space } \\
\text { utilization of } \\
\text { overcrowded old } \\
\text { downtown area } \\
\text { The flood relief in the } \\
\text { lowland area }\end{array}$ & $\begin{array}{l}\text { Sewer line: } 4.29 \mathrm{~km} \\
\text { Rainwater pumping } \\
\text { station: } 250 \mathrm{~m}^{3} / \mathrm{min} \\
\text { drain tunnel: } \mathrm{D}=4.3 \mathrm{~m} \text {, } \\
\mathrm{L}=1.07 \mathrm{~km}\end{array}$ \\
\hline 3. Andong & $\begin{array}{l}\text { Area to be supposed to the } \\
\text { separate sewer system } \\
\text { project } \\
\text { Mountainous terrain around } \\
\text { city area, flooding of } \\
\text { lowland } \\
\text { Sanitary Sewer System }\end{array}$ & $\begin{array}{l}\text { Reduction of project cost } \\
\text { through simultaneous } \\
\text { maintenance with rainfall } \\
\text { and sewage pipe }\end{array}$ & $\begin{array}{l}\text { Sewer line: } 30.48 \mathrm{~km} \\
\text { Rainwater pumping } \\
\text { station: } 380 \mathrm{~m}^{3} / \mathrm{min} \\
\text { drainage equipment: } \\
\text { 1,937ea }\end{array}$ \\
\hline 4. Cheonan & $\begin{array}{l}\text { Short-term inflow of surface } \\
\text { water and surface run-off } \\
\text { water during heavy rains } \\
\text { from low-lying steep slope } \\
\text { area } \\
\text { Sanitary Sewer System }\end{array}$ & $\begin{array}{l}\text { Prevention of flooding } \\
\text { due to introduction of } \\
\text { catchment facilities, } \\
\text { prevention of inflow of } \\
\text { road surface water } \\
\text { Reductions in } \\
\text { downstream inflows due } \\
\text { to new storage tank }\end{array}$ & $\begin{array}{l}\text { Sewer line: } 8.31 \mathrm{~km} \\
\text { Drain tunnel : } \\
D=3.0 \mathrm{~m}, \mathrm{~L}=1.07 \mathrm{~km}\end{array}$ \\
\hline 5. Boseong & $\begin{array}{l}\text { Strong sewage drainage } \\
\text { capacity } \\
\text { Low-lying areas } \\
\text { Sanitary Sewer System }\end{array}$ & $\begin{array}{l}\text { Suggest measures to } \\
\text { improve the drainage } \\
\text { system in the area } \\
\text { sanitary sewer completed } \\
\text { Maximize existing } \\
\text { pipeline utilization by } \\
\text { reducing peak runoff }\end{array}$ & $\begin{array}{l}\text { Sewer line: } 3.45 \mathrm{~km} \\
\text { Rainwater pumping } \\
\text { station:1place } \\
\text { substitute }\end{array}$ \\
\hline 6. Seochun & $\begin{array}{l}\text { Low-lying submergence due } \\
\text { to the influence of river } \\
\text { water level } \\
\text { Inadequate investment in } \\
\text { sewerage system and lack of } \\
\text { main drainage line } \\
\text { Combined Sewer system }\end{array}$ & $\begin{array}{l}\text { Establishment of } \\
\text { rainwater pumping } \\
\text { station and reconstruction } \\
\text { of main drainage system }\end{array}$ & $\begin{array}{l}\text { Sewer line: } 10.6 \mathrm{~km} \\
\text { Rainwater pumping } \\
\text { station: } 2 \text { place } \\
\mathrm{Q}=1,200 \mathrm{~m}^{3} / \mathrm{min} \\
\mathrm{Q}=490 \mathrm{~m}^{3} / \mathrm{min}\end{array}$ \\
\hline
\end{tabular}


Table 2: The population and area safe from flooding by the model project.

\begin{tabular}{|c|c|c|c|c|c|}
\hline \multirow{2}{*}{ City } & \multirow{2}{*}{$\begin{array}{c}\text { Drainage } \\
\text { Gimhae }\end{array}$} & Area & $\begin{array}{c}\text { Population } \\
\text { (households/people) }\end{array}$ & $\begin{array}{c}\text { Flood Damage } \\
\text { (No) }\end{array}$ & $\begin{array}{c}\text { Flood Area } \\
\text { (ha) }\end{array}$ \\
\cline { 5 - 7 } & Halchun & $1.357 \mathrm{~km}^{2}$ & $4,012 / 11,635$ & 110 & 5.1 \\
\hline \hline \multirow{2}{*}{ Bucheon } & Yoehyeon & $0.273 \mathrm{~km}^{2}$ & $1,196 / 3,469$ & - & - \\
\hline Andon & Chung-gu2 & $0.90 \mathrm{~km}^{2}$ & $1,184 / 2,332$ & 185 & 15.39 \\
\hline \multirow{2}{*}{ Cheonan } & Seongjung & $1.37 \mathrm{~km}^{2}$ & $9,377 / 18,796$ & 172 & 30.67 \\
\cline { 5 - 7 } & Shinbu & $0.63 \mathrm{~km}^{2}$ & $2,842 / 6,720$ & 131 & 12.33 \\
\hline Boseong & Bulkyo & $1.28 \mathrm{~km}^{2}$ & $2,067 / 4,341$ & 512 & 25.8 \\
\hline Seochun & Seochun & $2.97 \mathrm{~km}^{2}$ & $5,742 / 12,920$ & 683 & 30.4 \\
\hline \hline Total & & $15.1 \mathrm{~km}^{2}$ & $54,299 / 135,485$ & 2,155 & 157.89 \\
\hline
\end{tabular}

due to securing safety against flooding and promoting development projects related to the area.

Reduce constraints on development of upstream area by expanding drainage capacity of main sewer system.

\subsection{Urban water environment improvement}

Improvement of the sewer drainage facilities reduces stink and river ecological hindrance caused by overflow into the discharge stream. Also, it provides a pleasant urban environment and stink prevention expectation.

Improve the water quality of the river by reducing the pollutant load of $5,947 \mathrm{~kg} / \mathrm{yr}$. by utilizing the sewage tunnel as the CSOs storage tank.

\subsection{Local economic invigoration and job creation effect}

Activate regional economy by the participation of local construction companies, priority employment of local residents, utilization of local production materials, and use of local construction equipment.

Activate regional economy by revitalization of commercial area due to flood relief and increase of commercial population.

Create various jobs of municipal construction and maintenance manpower by implementing rainwater pumping station and sewer line rehabilitation project. 


\subsection{The effect of technology development}

By analysing the watershed characteristics of the target area, the surface runoff and the pipe runoff in the sewage system using the dual drainage model, Drainage ability of the sewer system is verified. The adequacy and effect of flood control facilities is estimated.

RTC system that controls and collects the operation, repair, and hydrological data of sewage facilities in real time was established. There was development of rainwater management technology and increase utilization as important data for flood control.

Multi-purpose tunnels were installed in the underground of the downtown area (Busheon, Cheonan) where the site space not sufficient. As well as storage and transport of rainfall, it can to improve river water quality by smooth rainwater exclusion and treatment of early storm water. The sewer tunnel installed in this time was the first successful attempt to build a sewer tunnel in Korea and will be used in area with high urbanization such as Seoul in the future.

\subsection{Introduction of eco-friendly technology}

In this time, low-impact development technology utilizing small-scale, distributed naturefriendly techniques which is introduced newly reduces non-point pollution and carbon emissions through recycling of resources and implement eco-friendly construction.

\section{FUTURE RESEARCH PLAN}

Guidelines for maintenance and operation of flood prevention will be established soon. Based on the accomplishment of the preceding project for urban flood prevention, the contents of the whole process such as institutional procedures, considerations, and measures for the causes of inundation will be summarized and applied to future flood prevention projects.

Through the analysis of the utilization, effects and problems of new technologies such as RTC system, double dual drainage system and sewer tunnel applied for the first time in Korea, the improvement measures for new technologies will be prepared. The Korea government with KECO will create a mid-term and a long-term master plan for preventing flood in urban areas, taking into consideration flooding and damage status, causes of flooding, local characteristics, etc. Those plans will be applied for 107 flooding areas by 2025 . It will make it possible to be free from flooding mostly in Korea.

Sewer management system should be improved more, revised and enacted to prepare for the current change of climate conditions and rainfall patterns such as sewerage law, facility standard, sewerage construction standard specification, and guideline for public sewer operation.

Finally, Research and development applying eco-friendly technology should be conducted continuously and the forth industrial revolution concept will be introduced in the sewer system maintenance.

\section{REFERENCES}

[1] Statistics Korea, "Statistics of Sewerage", 2016.

[2] Design Guidelines for Sewerage Facilities in Korea; Ministry of Environment (ME) Republic of Korea, 2011.

[3] Choi, Y., the Policy of Water Management in Seoul, Waterworks Research Centre, 2015. 